\title{
Discussion on the Organization and Management of the Graduation Design (Thesis) of the Practical Education in the Universities of Applied Sciences
}

\author{
Qiuju Zeng \\ Huanghe Science and Technology \\ Zhengzhou, Henan, China, 450006 \\ e-mail : 453857180@qq.com
}

\begin{abstract}
The graduation design (thesis) of the practical education in the universities of applied sciences is the longest study stage, which starts with topic selection and ends with oral defense. It is a painstaking and creative labor process where theories are integrated with practice, and it is directly related to the tenet of schooling quality and practical education, the implementation of application-targeted talents educational programs and students' overall quality and so on. This paper discusses the general principles and requirements for improving and assuring the quality of graduation design (thesis) and points out that three-level management (from the university, the departments, and the teaching and research sections) should be carried out by establishing detailed executive plans, work flow sheets, and conducting analysis and evaluation upon the graduation design results. This paper also proposes the measures to further standardize the organization and management of graduation design process.
\end{abstract}

Keywords-Universities of applied sciences; practical education; graduation design (thesis); management

\section{INTRODUCTION}

Graduation design (thesis) is the longest study stage, which starts with topic selection and ends with oral defense. The completion quality of graduation design in each stage and link will directly influence the graduation design quality, students' overall quality and improvements of innovation ability, which requires that adequate attention should be paid to the graduation design of practical education, and that organization and management should be intensified in practice by universities.

\section{PRINCIPLE FOR GRADUATION DESIGN (THESIS) OF PRACTICAL EDUCATION}

Graduation design (thesis) is a painstaking and creative labor process where theories are integrated with practice and the sole systematic project for college students during the study, and the graduation design level is directly related to the tenet of schooling quality and practical education, the implementation of application-targeted talents educational programs and students' overall quality and so on.

\section{A. The principle where the students are subjects instructed by teachers}

Graduation design is a bridge through which the students find their ways to social practice from class, and through which the students begin to step into the age of adult who starts independent thought and practice from the point in professional knowledge, and it forms a connecting link between the preceding and the following, and it is a key point for student's up-growth as an individual and also a transition stage for national and social talent fostering, the special nature determines that there must be contradictions between students' independence and teachers' instruction during the operation process. On the one hand, according to the principle of education and cultivation, the students are orientated and encouraged for independent thought; on the other hand, characteristics in the transition stage shall be regarded as well, and the teachers' instruction and elicitation cannot be completely abandoned, and teachers are required to well serve the students and be satisfactory instructors, illuminators and whetstones for the students till the students' success in achievement.

\section{B. The principle where practice is centered and combined with theoretical research}

The difference between practice and theory rests with the utility, since the graduation design cannot be restricted to oral expression and character reasoning, the pertinence and operability are much regarded, if the students are required to improve technical level and practice ability through graduation design aiming at production, equipment, new product development and new technique promotion after surveys in enterprises, they should do according to their abilities and depend on their practice abilities, meanwhile, the graduation design shall be towards some extent challenging and able to stimulate and foster students' potential practice abilities as well.

\section{The principle where innovation is oriented and restricted by standards}

Innovation is the source of life for all education and practice, and the innovation ability is the true source of 
social wealth. Accordingly to foster students' innovation ability becomes a natural object in students' education, obviously, which must be fully and completely shown in the graduation design, an important part in the education.

\section{The principle of being future-oriented and combined with courses}

Graduation design is a transition stage connecting the link between the preceding and the following for students, so it cannot be regarded only as a summary and review over the past courses, in the meantime, it is also a rehearsal for the students to engage in the social practice and its forward looking is obvious. Moreover, the first step for the students to access to social practice is based on the professional knowledge and skills learned in classes, which in the graduation design require students using what they have learned skillfully in practice.

\section{ORGANIZATION FOR GRADUATION DESIGN (THESIS) OF PRACTICAL EDUCATION}

Generally, rules related to organization and management are established in each university, however, most have no special operating provisions in mechanism and the enforcement regulations are imperfect as well. For example, there are no clear standards or indices for evaluation from topic selection, data collection, experiment or survey, paper writing, modification and final text to the paper's result evaluation, which causes a formalistic work flow of graduation design management in operation. Therefore, it is necessary to establish rational graduation design-related organization rules, basic systems and work flow of management affairs such as statements, diagrams, standards and the like.

\section{A. To establish and perfect standardized management organization and define the graduation design-related responsibilities}

The graduation design (thesis) management shall adopt three-level management including management from the university, from the departments and from the teaching and research sections.

First of all, vice president in charge of teaching is responsible for the university graduation design (thesis). Establish a university level "graduation design (thesis) leading group", whose members mainly include principals of relevant colleges, departments and sections, set up an office where the director of teaching and research section will serve as office director. The group's main responsibilities are to implement the policy and file instruction related to the graduation design (thesis) released by superior education authorities, establish or modify relevant rules and systems in the university, and conduct macro management upon the university's graduation design (thesis), examine and evaluate the graduation design (thesis) of colleges and departments, and make feedback to colleges (departments) in time and offer instructive opinions; organize colleges (departments) to summarize experience and exchange according to the graduation design (thesis), organize and review the oral defense and collection of excellent graduation design (thesis) in the university, and honor the university level instructors and organization managers, and deal with other graduation design (thesis) concerning the university and the like.

Colleges shall set up college or department-based graduation design leading groups, where the college president or dean in charge of teaching will take charge of the graduation design of his own unit. Main members consist of leaders of professional courses and basic courses, heads of teaching and research sections and teaching offices as well as professional teachers. The college's teaching offices will take charge of daily management of graduation design. The group's main responsibilities are mainly to implement and execute the university's file instruction, rules and systems related to the graduation practice and graduation design (thesis); formulate work plans and executive plans of graduation practice and graduation design (thesis); organize and review the graduation design topic of its own unit, verify the instructors' qualification, train teachers who participate in the instruction for the first time; review the eligibility of the students participating in the graduation design (thesis), and make proper and rational organization and arrangement; Organize and check the progress and quality of graduation design (thesis) of its own unit, research and solve existing problems; verify the organization name list of "Oral Defense Committee for Graduation Design (Thesis)" and instruct relevant work; review the graduation design (thesis) result of its own unit, organize and arrange the oral defense of its own unit, evaluate and recommend university-level excellent graduation design (thesis) and supervisors of its unit; make work summary concerning the graduation design (thesis) of its own, and hand in or keep relevant data as required and so on.

As for specialties, graduation design steering groups should be established in which supervisors and teachers of specialties or from teaching and research sections will participate, whose responsibilities are to fulfill and execute the rules and instruction concerning graduation design (thesis) from colleges or departments; recommend colleges (departments) excellent graduation design (thesis) topics and supervisors' name lists and organize the students for topic selection; review and prepare teaching conditions related to graduation design (thesis); review graduation design (thesis) tasks, organize and fulfill topic reports of graduation design (thesis); check supervisors' work, monitor the progress and quality of graduation design (thesis); organize and execute the review and oral defense of graduation design (thesis) as well as result evaluation; recommend colleges (departments) excellent graduation design (thesis) and supervisors; make careful work summary of graduation design (thesis), settle related costs, and collect graduation design (thesis) data as required and so on.

\section{B. To establish relevant rules and management systems}

Graduation design is complicated with multiple flows, where supervisors participate for instruction, meanwhile, it will be involved in relevant funds, and an improper link may affect the progress of graduation design. Accordingly universities need to standardize supervisors' qualification, 
work, duty, excellence standard, primary review, oral defense requirements and costs for instruction. The policy and file instruction concerning graduation design (thesis) from the superior educational authorities shall be carried out, meanwhile, according to the schooling orientation in application of universities, rules and systems concerning graduation design teaching shall be established or modified, and macro organization management shall be conducted on graduation design in universities, and award and punishment measures shall be established for the instruction quality of supervisors and the graduation design quality of the students so as to improve teachers' and the students' enthusiasms.

\section{To draw work flow diagrams of graduation design}

Graduation design leading groups of colleges in a university shall carry out and implement rules and systems concerning graduation practice and graduation design (thesis), and frame work plans and detailed executive plans concerning graduation practice and graduation design of their own, and take the college or specialty as a unit for graduation design (thesis), program diagram or graduation design (thesis) work flow sheets. The links needed by graduation design of the students and teachers offering instruction shall be regulated, with the links of graduation design as main line, basic requirements and instruction for teachers and basic requirements and key design points for the students shall be regulated. For example, the Graduation Design (Thesis) Instruction Manual of Huanghe S\&T College divides the graduation design into five stages namely basic stage, preparation stage, implementation stage, check stage and summary stage in the graduation design (thesis) work flow sheet, and the work links and times are regulated for each stage, and the tasks of responsible departments, teachers and students are distributed in details for each stage. A uniform, standard and relatively stable management system over the graduation design is established, with the system's implementation and continuous improvement, the graduation design management is kept in good order and with high efficiency.

\section{Measures to Manage Graduation Design (THESIS) OF PRACTICAL EDUCATION}

\section{A. To strengthen instruction and examination on the whole design process}

If the process of graduation design is poorly managed, it may indulge the students in graduation design and negligence of teachers in instruction. For example, subjectselecting and mid-term examinations are formalistic, which may cause eyewash and serious plagiarism by the students and so on. A whole course monitoring mechanism shall be set up over the graduation design to urge the students to report regularly and supervisors to instruct carefully, and the staged examination and restriction shall be strengthened so as to find problems and solve them in time.

During the graduation design, supervisors play an important role in instructing the students to complete the graduation design, and play key roles whether in topic type, difficulty level, work load or in students' training, graduation design quality and the like. Accordingly supervisors are required to well master the university's talent fostering target and specialty education plan, and all links shall be carefully designed as per the target with instruction enforced in the design, and all links shall be controlled strictly. For example, whether the topic of graduation design is proper or the work load is rational are both key points for the well-going of graduation design, and supervisors, principals of specialty or departments shall well control and review each link of graduation design. The students are subjects to achieve graduation design, and universities shall clarify disciplines and requirements to the students during the graduation design, establish stimulating rules to promote the students to exert requirements of their own and internal drives in restriction, and enable the students receive fostering and training in all aspect in the stage.

Teaching management and colleges shall intensify process control, establish supervision and instruction groups during the design, supervise and instruct the students in all links of graduation design, exchange opinions with supervisors for any problems arising, and take measures to assure the graduation design quality. Execute supervisor responsibility system for the graduation design, and each supervisor shall take full responsibility for all links of the graduation design of students. Rules shall be established to improve the responsibilities of supervisors. In addition, midterm examination shall be done on the graduation design, main contents to be examined mainly include students' understanding of graduation design task, progress and completion of graduation design, design period, problems arising out of the design, defects of supervisors existing in instruction, quality of previous work completed and so on, multiple modes shall be adopted for check in all aspects, all specialties shall make self check and mutual check, expert supervising groups and the university will make spot checks. The midterm examination may find and solve problems existing in the graduation design so as to ensure the smooth progress of the subsequent work.

\section{B. To strictly control reading and appraisal, oral defense and examination}

After completion of the graduation design, students' design data, achievements and graduation thesis will be read and appraised, and receive oral defense, check and review. The strict control on the link means to conduct strict control on students' graduation design quality and supervisors' abilities.

Generally after the graduation design is read and appraised by supervisors, it will be reviewed by the chief supervisor with relevant results and grades given. The review shall follow the graduation design (thesis) scoring standard established by the university, and the results will be verified carefully as per the scoring standard. Based on careful instruction and appraisal, supervisors and chief supervisor may exchange opinions to avoid subjective appraisal. During the oral defense, specialties or teaching and research offices shall establish "Graduation design (thesis) oral defense committee" or "Oral defense group", and appoint an academic leader as group leader for collective control; clarify 
numbers of the members of the oral defense group and give requirements to technical titles of the group members. For example, the Graduation Design (Thesis) Instruction Manual of Huanghe S\&T College provides that there are at least five members for the oral defense committee who must have medium level or above professional technical titles, of whom, there are at least 3 members with deputy senior titles, and the principal of the oral defense committee or group must have senior title. The review of graduation design is generally achieved by teachers of relevant specialty, according to subjects and specialties, certain teachers will be arranged to other colleges for exchange and review so as to absorb the review styles and quality requirements of other colleges, and improve the defects of their own and promote the quality of fostering professional talents.

\section{Analysis and appraisal on the graduation design result}

Judging from students, analysis and appraisal shall be made on from students' complex training, work load, application of elementary knowledge to basic skills and complex capabilities; judging from the university, analysis and appraisal shall be made on the result distribution of graduation design, supervisors' and appraisers' comments, judge whether the result distribution is rational, the supervisors' and appraisers' comments reflect students' true level of graduation design comprehensively and accurately. The analysis and appraisal shall be taken as whole and detailed deeply to find problems and put forward opinions for improvement so as to benefit the students of next years to improve the graduation design quality and management quality. Meanwhile, colleges shall be organized to summarize and exchange relevant experience in the graduation design (thesis), arrange the oral defense and collection of excellent graduation design (thesis) in the university, and honor the university-level excellent supervisors and organization managers.

It is a long and complicated work for universities, teachers and teaching managers to strengthen the standardized organization and management of graduation design process. Only by adhering to strict management, deepening teaching reform, solving difficulties and promoting the reform and progress of graduation design can we continuously improve the quality of graduation design and produce more and more highly qualified people.

\section{REFERENCES}

[1] Kang Jingli \& Dong Shaoxiao. How to Orient Local Colleges: Breakout from Dislocated Competition of Applied Undergraduate Universities [N]. China Education Newspaper, 2011-11-01 (02).

[2] The General Office of the Ministry of Education. Notification of the General Office of the Ministry of Education on Strengthening the Task of Graduation Design (paper) of Ordinary Institutions of Higher Learning, [EB/OL]. (2004-04-08) [2014-06-20]. http://www.chinalawedu.com/news/1200/22598/22615/22796/2006/3/ qi08662859351213600227550-0.htm.

[3] The Ministry of Education. Several Opinions of the Ministry of Education on Comprehensive Improvement of the Quality of Higher Education [EB/OL]. (2012-03-16) [2014-06-20]. http://www.gov.cn/zwgk/2012-04/20/content_2118168.htm.
[4] Written by Gao Lin et al. Introduction of Applied Undergraduate Education [M]. Beijing: Science Press, 2007:193. 